\title{
The emissions reduction possibility of sulphur compounds of vessels sailing in Emission Control Areas (ECA)
}

The article presents legal regulations, together with the characteristics of Emission Control Areas (ECA). It is connected with the new limit sulfur emissions in those areas. In this article, the advantages and disadvantages of various solutions, i.e. switching to low sulphur distillates, installing the marine scrubber device and using of liquefied natural gas (LNG) as ship's main fuel have been considered. Each of these solutions was described in respect of technological review, by the possibility of reducing harmful compound from exhaust gases, to investment costs. In another part of this thesis, there are the calculations of costs of fuel and necessary modifications for a selected passenger-car ferry. Costs were assessed for all of the mentioned solutions. The article was completed conclusions indicating which way is the most cost-effective.

Key words: environmental protection, sulfur compounds, power engines, marine scrubbers, shipping

\section{Introduction}

The development of technology throughout history has always been to facilitate the life of human. In shipbuilding, as a field of transport, there is also a gigantic technological leap. Ship propulsion has changed from simple ways like sail, steam engines to today's widely used diesel engines.

Such progress is unfortunately the price, and it is the degradation of the natural environment. Marine engines produce large amounts of toxic compounds to the atmosphere. The most commonly used heavy fuel oil (HFO) during combustion reactions in the engine emits mainly sulfur oxides $\left(\mathrm{SO}_{\mathrm{x}}\right)$, oxides of nitrogen $\left(\mathrm{NO}_{\mathrm{x}}\right)$ and carbon dioxide $\left(\mathrm{CO}_{2}\right)$. To limit the effects of human activities on the seas and oceans, the International Maritime Organization (IMO) has introduced Emission Control Area (ECA). Since January 1, 2015 new regulations have been introduced to limit the emission of sulfur compounds. According to new standards, the sulfur content of fuel in control zones may not be higher than $0.1 \%$ [7]. To meet these requirements, shipowners operating in these areas had to develop technical solutions to be able to move further in these areas. The easiest way is to switch from heavy fuel to more expensive marine diesel oil with reduced sulfur content (Marine Gas Oil). The disadvantage of this solution is the higher price and higher wear of the mechanical components of the engine. Another possibility is the installation of exhaust gas scrubbers, unfortunately this solution is expensive and it is not always possible to mount it on an existing vessel. Another alternative is to adjust the internal combustion engine to supply the liquefied natural gas (LNG), gas supply significantly reduce the emission of harmful compounds to the atmosphere and the fuel itself is cheaper. This solution is also not devoid of defects. And the biggest one is transport itself, hindered by the need to cool the liquefied gas to $-163^{\circ} \mathrm{C}$. In the case of new ships, there is no problem with the placement of suitable tanks, but in older structures it can be a serious challenge [4].

\section{MARPOL Convention and characteristics of Emission Control Areas}

The International Convention for the prevention of pollution from ships (MARPOL) is an international agreement which was adopted at the International Conference on Marine Pollution. The conference was organized by the IMO in October 1973. The Convention was modified in 1978 at the International Conference on Tanker Safety and Pollution Prevention. Convention is known as MARPOL 73/78. The next modification was made in 1997, when an Annex VI was added to deal with the prevention of air pollution by ships. Specific regulations describe the requirements for reducing nitrogen oxides $\left(\mathrm{NO}_{\mathrm{x}}\right)$, sulfur oxides $\left(\mathrm{SO}_{\mathrm{x}}\right)$, particulate matter (PM), volatile organic compounds (VOC) and substances that deplete the ozone layer. Regulations on the sulfur content of fuels in special and globally areas were detailed in the Annex. On January 1, 2015, the sulfur directive was amended to reduce the maximum sulfur content of marine fuels to $0.1 \%$ at Emission Control Areas [6]. Permissible sulfur content limits for fuel in particular years are shown in Table 1.

Special, sharper rules apply in defined special areas. Special area means a sea area where the use of extraordinary means of preventing marine pollution is required. This is due to a large number of ships and a greater risk of damage to the marine environment. Special areas for the purpose of this Annex are: The Baltic Sea, the Mediterranean Sea, the North Sea, the Black Sea, the Red Sea, the Antarctic area and the Caribbean region.

Table 1. Permissible limits of sulfur content in fuel [3]

\begin{tabular}{|c|c|c|}
\hline \multirow{2}{*}{ Date } & \multicolumn{2}{|c|}{ Limit of sulfur content in fuel $[\% \mathrm{~m} / \mathrm{m}]$} \\
\cline { 2 - 2 } & $\mathrm{SO}_{\mathrm{x}} \mathrm{ECA}$ & Global \\
\hline $2010 \mathrm{y}$. & $1.5 \%$ & $4.5 \%$ \\
\hline $07.2010 \mathrm{y}$. & $1.0 \%$ & \multirow{2}{*}{$3.5 \%$} \\
\hline $2012 \mathrm{y}$. & & \multirow{2}{*}{$3.5 \%$} \\
\hline $2015 \mathrm{y}$. & \multirow{2}{*}{$0.1 \%$} & $0.5 \%$ \\
\hline $2020 \mathrm{y}$. & & \\
\hline
\end{tabular}

For the need for new regulations, special emission control zones have been created. In these zones there are much more stringent ecological requirements. At first the zones were named as sulphur emission control area and $\mathrm{NO}_{\mathrm{x}}$ emission control area, but they have been renamed as ECA and their meaning has been extended. Controlled areas are mainly around the most ecologically-polluted ports in the 
world, ie the Baltic Sea, the North Sea and its approaches, and the English Channel.

Such zones also apply along the 200-mile wide coast of the United States and Canada. There are also talks on possible new ECAs such as the Mediterranean and Japan (Fig. 1). In Emission Control Areas, there are tightening of emissions to the atmosphere of such compounds as: such as $\mathrm{SO}_{\mathrm{x}}$, $\mathrm{NO}_{\mathrm{x}}, \mathrm{PM}$, volatile organic compounds (VOC) [3].

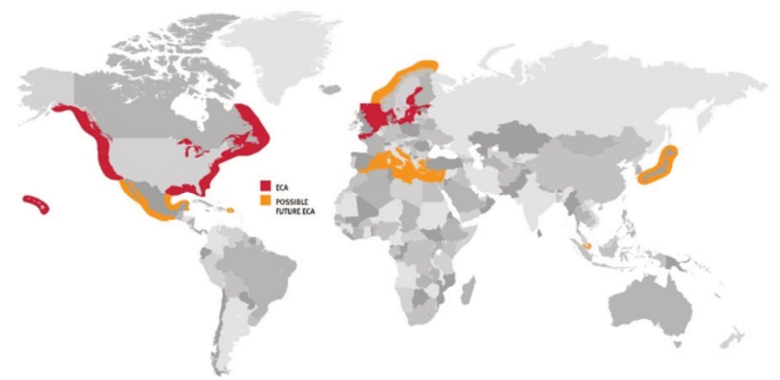

Fig. 1. Current areas ECA (red) and possible future zones (orange) [10]

One of the harmful substances entering the atmosphere with exhaust gases is sulfur oxides $\left(\mathrm{SO}_{\mathrm{x}}\right)$. They are formed by oxidation (combustion) of marine fuel, where the sulfur content is up to $5 \%$. Sulfur oxides, like nitrogen oxides, combine with water vapor in the atmosphere to cause acid rain, acidification of groundwater, water bodies and soil. Acidic groundwater flushes the potassium from the ground, and the effect is to reduce its fertility. In addition, heavy metals are dissolved. There are three basic groups of sulfur oxides: sulfur oxide II (SO), sulfur oxide IV - $\left(\mathrm{SO}_{2}\right)$ and sulfur oxide $\mathrm{VI}-\left(\mathrm{SO}_{3}\right)$. Sulfur oxides are also responsible for the corrosion of the equipment made of metal, in which combustion takes place, as well as in the surrounding environment. They also cause greater wear of mechanisms and machines. To the human body sulfur oxides get into the process of breathing, damaging the airways. After getting into the bloodstream, they accumulate in the liver, spleen and lymph nodes.

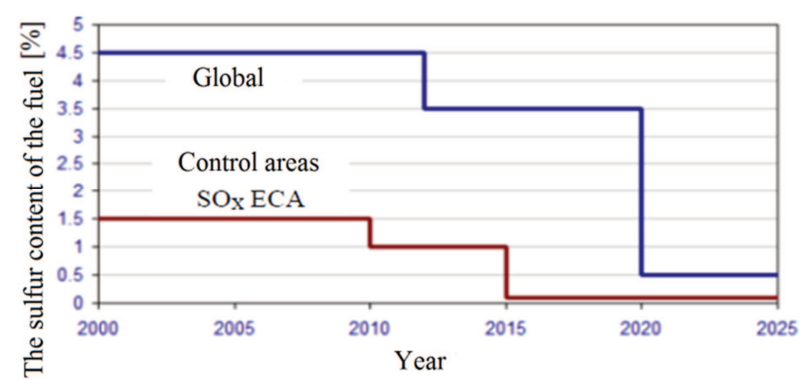

Fig. 2. Permissible sulfur content in fuel according to Annex VI MARPOL [3]

Limitation of the release of harmful sulfur oxides $\left(\mathrm{SO}_{\mathrm{x}}\right)$ produced by burning of fuel on ships is carried out in accordance with the requirements of Regulation 14, Annex VI of the MAR-POL Convention by limiting the sulfur content of marine fuels (Fig. 2).

\section{Possible solutions to reduce sulfur compounds emissions}

The sulfur content of the fuel is strongly associated with the crude oil. During the combustion process, the sulfur is oxidized, producing $\mathrm{SO}_{2}$ dioxide and $\mathrm{SO}_{3}$ trioxide at a ratio of 15: 1. Sulfur oxide emissions are subject to limits as $\mathrm{SO}_{\mathrm{x}}$. The ways to limit the $\mathrm{SO}_{\mathrm{x}}$ content can be the use of low sulfur fuels or exhaust gases cleaning by treating them in devices called scrubbers. These devices effectively remove sulfur oxides from the exhaust gases, but the problem is neutralization of waste. On the other hand, the transition to low-sulfur fuel is related to the economic factor - fuel prices are linked to sulfur content. The reason is the expensive desulphurisation process. The future solution for the reduction of sulfur oxide emissions is the supply of marine engines by liquefied natural gas (LNG) and methane. This is an interesting solution because it reduces $\mathrm{SO}_{\mathrm{x}}$ emission, so it meets high requirements in ECA zones and is 20-40\% cheaper than crude oil. Alkaline lubricant additives in the engine neutralize a small fraction of the sulfur contained in marine fuel, converting it into neutral calcium. However, the amount of neutralized sulfur is so small that it is not considered to be an effective way to reduce $\mathrm{SO}_{\mathrm{x}}$ emissions [2].

\section{Economic analysis of possible solutions to reduce emissions of sulfur}

Considering the technical solutions to reduce emissions of sulfur oxides $\mathrm{SO}_{\mathrm{x}}$ in ECA zones one of the more important issues is the costs associated with the required modernization of the fleet. Costs are the factor most influencing the decision of the shipowners. To approximate the financial issue of technological solutions to reduce $\mathrm{SO}_{\mathrm{x}}$ emissions, you should make an example cost estimate for a given lifetime of the vessel.

To create cost estimates for individual construction solutions, the MF Stena Spirit passenger-car ferry on the Gdynia-Karlskrona route was selected (Fig. 3). This ferry has been chosen as an example of a ship for years in service, and the main task for shipowners is to adapt to the current standards just such units.

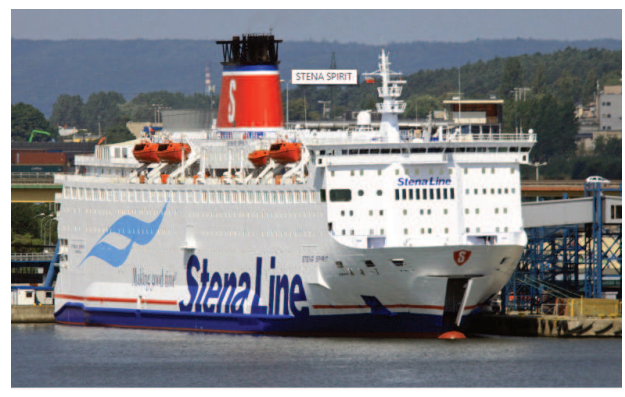

Fig. 3. MF Stena Spirit ferry [12]

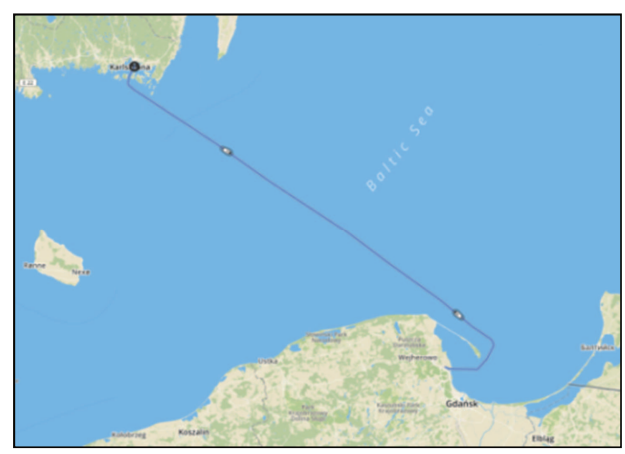

Fig. 4. MF Stena Spirit ferry route [13] 
The ferry route is a permanent connection from Gdynia to Karlskrona in Sweden of 174 nautical miles (Fig. 4). The one-way journey takes about 10 hours, and the MF Stena Spirit ferry crosses this journey twice a day and 12 times during the week. As an example, sailing time for calculations was assumed to be 10 years.

\subsection{Operation on low sulfur fuel}

LSMGO low sulfur fuel used in ECA zones (ie throughout the route) was used for calculations. The specific fuel consumption of the main engine is $g_{e}=160 \mathrm{~g} / \mathrm{kWh}$, but by auxiliary engine is $g_{e}=175.5 \mathrm{~g} / \mathrm{kWh}$; In addition, the nominal power of the main engine equals $\mathrm{N}_{\mathrm{n}}=7355 \mathrm{~kW}$ and auxiliary engine $\mathrm{N}_{\mathrm{n}}=1265 \mathrm{~kW}$ [9].

\section{Diesel oil consumption during the voyage}

The nominal consumption of fuel by the main engine and auxiliary engines within one hour is determined by the formulas [5]:

$$
\begin{aligned}
\mathrm{G}_{\mathrm{g}} & =\mathrm{g}_{\mathrm{e}} \cdot \mathrm{N}_{\mathrm{n}} \cdot 10^{-6}[\mathrm{t} / \mathrm{h}] \\
\mathrm{G}_{\mathrm{p}} & =\mathrm{g}_{\mathrm{ep}} \cdot \mathrm{N}_{\mathrm{n}} \cdot 10^{-6}[\mathrm{t} / \mathrm{h}]
\end{aligned}
$$

where: $g_{e}-$ the actual specific fuel consumption by main engine, $g_{e p}-$ the actual specific fuel consumption by auxiliary engine, $\mathrm{N}_{\mathrm{n}}$ - the nominal power of the main engine, $\mathrm{N}_{\mathrm{np}}$ - the nominal power of the auxiliary engine.

Accepted values were inserted into the formula for diesel oil according to (1) i (2):

$$
\begin{gathered}
\mathrm{G}_{\mathrm{g}}=160 \cdot 7355 \cdot 10^{-6}=1.18 \mathrm{t} / \mathrm{h} \\
\mathrm{G}_{\mathrm{p}}=175.5 \cdot 1265 \cdot 10^{-6}=0.22 \mathrm{t} / \mathrm{h}
\end{gathered}
$$

If you assume that during the cruise of the MF Stena Spirit ferry all 4 main engines and two of the five power generators were running, the hourly fuel consumption will be as follows:

$$
\mathrm{G}_{\text {gip }}=4 \cdot 1.18+2 \cdot 0.22=5.1 \mathrm{t} / \mathrm{h}
$$

Having the information that the ferry is on the route for 20 hours a day you can count daily consumption:

$$
\mathrm{G}_{\text {gip }}=20 \cdot 5.1=102 \mathrm{t} / \mathrm{h}
$$

In this regard, that the ferry serves this route 6 times a week and a year consists of 52 weeks you can estimate fuel consumption for a year:

$$
\mathrm{G}_{\mathrm{gip}}=102 \cdot(6 \cdot 52)=31824 \mathrm{t} / \mathrm{year}
$$

Assuming that the ferry will swim for 10 years, LSMGO fuel consumption in this term has been calculated:

$$
\mathrm{G}_{\text {gip }}=31824 \cdot 10=318240 \mathrm{t} / 10 \text { years }
$$

Based on the assumption that the world price of low sulfur fuel is fixed and is 440 USD per ton [11], the fuel cost of a given period of time can be estimated:

\section{$318240 \cdot 440=140025600 \$$}

The main engines and auxiliary engines have been able to supply diesel oil at the time of production, so in this case it is not necessary to replace fuel pumps and injectors. In this way, the investment costs for this solution practically does not exist.

\subsection{Assembly of exhaust gas scrubbers}

Considering the advantages and disadvantages of different types of scrubbers, it can be concluded that the most appropriate choice for the specifically selected passenger and car ferry will be wet scrubber in a closed circuit. This choice was dictated by the ferry route, where it is not possible to dump water from the wash circuit directly into the sea, which is possible with open scrubbers. Dry scrubbers do not reduce nitrogen oxides, which again would increase the cost of investing in equipment called Selective Catalytic Reduction (SCR).

The disadvantage of the solution chosen is the costs associated with the sludge generated during the rinsing process to the appropriate receiving facilities on land and the purchase costs of sodium hydroxide $(\mathrm{NaOH})$ as a necessary means to operate the scrubber.

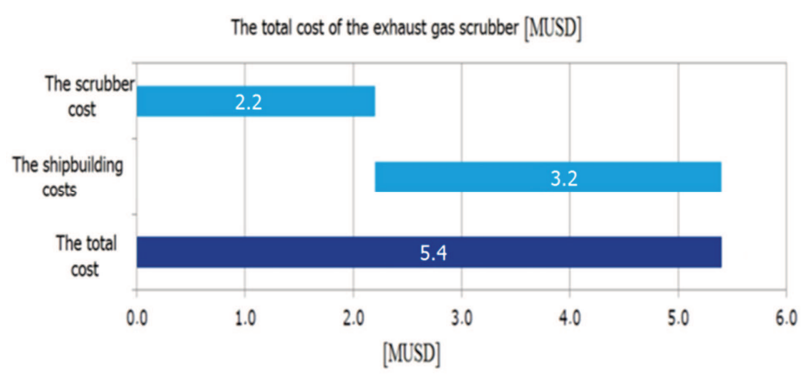

Fig. 5. The installing cost of the exhaust gas scrubber according to DNV GL [1]

The price of sodium hydroxide $(\mathrm{NaOH})$ is $50-250 \$ / \mathrm{m}^{3}$, which translates into an average cost of use of the scrubber of 20-50 \$ per metric ton of fuel burned. The amount of cash spent on the scrubber is 3-4 million USD depending on the manufacturer. Obviously, shipbuilding costs, such as assembly and necessary ship repairs, are included. Such costs are difficult to estimate due to market dependence. Some sources give about $\$ 1$ million, and others give up about $\$ 3$ million $[3,26]$. The sample cost according to the classification society DNV GL is shown in Fig. 5.

The need of the analysis presented in the article, as the total cost of the exhaust gas scrubber together with shipbuilding costs $\$ 5$ million have been adopted. This amount will be added to the purchase price of heavy fuel used to power main engines and generating sets on the selected MF Stena Spirit.

\section{Heavy fuel oil consumption during the voyage}

The specific consumption of heavy fuel by the main engine is $\mathrm{g}_{\mathrm{e}}=164 \mathrm{~g} / \mathrm{kWh}$, while by auxiliary motor $\mathrm{g}_{\mathrm{e}}=180$ $\mathrm{g} / \mathrm{kWh}$ [9].

Accepted values were inserted into the formula for fuel according to (1) i (2):

$$
\begin{aligned}
& \mathrm{G}_{\mathrm{g}}=164 \cdot 7355 \cdot 10^{-6}=1.21 \mathrm{t} / \mathrm{h} \\
& \mathrm{G}_{\mathrm{p}}=180 \cdot 1265 \cdot 10^{-6}=0.23 \mathrm{t} / \mathrm{h}
\end{aligned}
$$

As in the previous case, it was assumed that during the cruise of the MF Stena Spirit ferry all four main engines and two of the five generating sets were running. The hourly fuel consumption will be equal: 


$$
\mathrm{G}_{\text {gip }}=4 \cdot 1,21+2 \cdot 0.23=5.3 \mathrm{t} / \mathrm{h}
$$

As before, assuming that a ferry is on the route for 20 hours a day, daily consumption is calculated:

$$
\mathrm{G}_{\text {gip }}=20 \cdot 5.3=106 \mathrm{t} / \mathrm{h}
$$

Annual fuel consumption (route operated 6 times a week, year $\approx 52$ weeks):

$$
\mathrm{G}_{\text {gip }}=106 \cdot(6 \cdot 52)=33072 \mathrm{t} / \text { year }
$$

So within 10 years the ferry will consume:

$$
\mathrm{G}_{\text {gip }}=33072 \cdot 10=330720 \mathrm{t} / 10 \text { years }
$$

Assuming the world price of fuel is constant and is $\$$ 248 per tonne [11], you can estimate the fuel cost of a given period of time:

\section{$330720 \cdot 248=82018560 \$$}

However, keep in mind the average cost of using a scrubber. It is $\$ 20-50$ per metric ton of fuel burned. This is the cost of buying sodium hydroxide $(\mathrm{NaOH})$ and leaving sludge in the ports. For the purpose of analysis, the cost of using a scrubber will be an average, that is $\$ 35$ per ton of fuel. In this way, additional costs are generated:

$$
330720 \cdot 35=11575200 \$
$$

In the final account we also include the cost of buying and installing of the exhaust gas scrubbers as 5 million USD:

$$
82018560+11575200+5000000=98593760 \$
$$

This amount is lower than the use of low sulfur fuel in the same period of time.

\section{3. Reconstruction of the unit for liquefied natural gas supply (LNG)}

The passenger/car ferry accepted for analysis can be adapted to work on liquefied natural gas (LNG) by replacing main and auxiliary engines for dual fuel engines (DF). The most similar dual-fuel engine is the 8L50DF with a power of $\mathrm{N}_{\mathrm{n}}=7600 \mathrm{~kW}$. They were also chosen auxiliary engines with a nominal power of $\mathrm{N}_{\mathrm{np}}=1280 \mathrm{~kW}$.

During dual-fuel operation, when natural gas and pilot fuel are used for the engine, the gas consumption is given in $[\mathrm{kJ} / \mathrm{kWh}]$. To determine the cost of gas to power the engine, calculate the gas consumption in $\mathrm{m}^{3}$, using the gas heat rate given by the engine manufacturer:

$$
7258 \mathrm{~kJ} / \mathrm{kWh} \cdot 7600 \mathrm{~kW}=55160800 \mathrm{~kJ} / \mathrm{h}
$$

which means:

$$
55160800 \mathrm{~kJ} / \mathrm{h}=55160.8 \mathrm{MJ} / \mathrm{h}
$$

The liquefied natural gas consumption was calculated for calorific value of $34.43 \mathrm{MJ} / \mathrm{m}^{3}$ for $\mathrm{GZ}-50$ gas under normal conditions (temperature $-0^{\circ} \mathrm{C}$, pressure $101.3 \mathrm{kPa}$ ). Hourly gas consumption in one main engine:

$$
5516.8 \mathrm{MJ} / \mathrm{h}: 34.43 \mathrm{MJ} / \mathrm{m}^{3}=1602.11 \mathrm{~m}^{3} / \mathrm{h}
$$

As with main engines, the gas consumption of auxiliary engines must be calculated:

$$
7809 \mathrm{~kJ} / \mathrm{kWh} \cdot 1280 \mathrm{~kW}=9995520 \mathrm{~kJ} / \mathrm{h}
$$

It means:

$$
9995520 \mathrm{~kJ} / \mathrm{h}=9995.5 \mathrm{MJ} / \mathrm{h}
$$

The liquefied natural gas consumption was calculated for a calorific value of $34.43 \mathrm{MJ} / \mathrm{m}^{3}$ for GZ-50 gas under normal conditions:

$$
\text { 9995.5 MJ/h : } 34.43 \mathrm{MJ} / \mathrm{m}^{3}=290.31 \mathrm{~m}^{3} / \mathrm{h}
$$

It should be noted, by burning gas, dual fuel engines consume certain amounts of liquid fuel as pilot fuel. These quantities will be included in the calculation.

The main and auxiliary engine fuel consumption for the hour was determined from the formula (1) and (2) for the specific fuel consumption by the main engine in dual fuel mode $\mathrm{g}_{\mathrm{e}}=1 \mathrm{~g} / \mathrm{kWh}$ and for the specific fuel consumption by the auxiliary engine in dual fuel mode $\mathrm{g}_{\text {ep }}=3.9 \mathrm{~g} / \mathrm{kWh}$ :

$$
\begin{gathered}
\mathrm{G}_{\mathrm{g}}=1 \cdot 7600 \cdot 10^{-6}=0,0076 \mathrm{t} / \mathrm{h} \\
\mathrm{G}_{\mathrm{p}}=3.9 \cdot 1280 \cdot 10^{-6}=0.0049 \mathrm{t} / \mathrm{h}
\end{gathered}
$$

We assume that all four main engines and two of the five generating sets were running during the cruise. The hourly consumption of liquefied natural gas is:

$$
\mathrm{G}_{\text {gip }}=4 \cdot 1602.11+2 \cdot 290.31=6989.06 \mathrm{~m}^{3} / \mathrm{h}
$$

The total hourly consumption of pilot fuel is:

$$
\mathrm{G}_{\text {gip }}=4 \cdot 0.0076+2 \cdot 0.0049=0.04 \mathrm{t} / \mathrm{h}
$$

If we already have both values, that is the hourly gas burning and the dose of pilot diesel oil in the main and auxiliary engines, we can calculate the fuel consumption: daily, annual and within 10 years. Similar to previous calculations, we assume that the ferry is on the route for 20 hours a day:

LNG:

$$
\mathrm{G}_{\text {gip }}=20 \cdot 6989.06=139781.2 \mathrm{~m}^{3} / \mathrm{h}
$$

diesel oil:

$$
\mathrm{G}_{\text {gip }}=20 \cdot 0.04=0.8 \mathrm{t} / \mathrm{h}
$$

Annual fuel consumption (route operated 6 times a week, year $\approx 52$ weeks):

LNG:

$$
\mathrm{G}_{\text {gip }}=139781.2 \cdot(6 \cdot 52)=43611734 \mathrm{~m}^{3} / \text { year }
$$

diesel oil:

$$
\mathrm{G}_{\text {gip }}=0.8 \cdot(6 \cdot 52)=249.6 \mathrm{t} / \text { year }
$$

This means that within 10 years the ferry will use:

LNG:

$$
\mathrm{G}_{\text {gip }}=43611734 \cdot 10=436117340 \mathrm{~m}^{3} / 10 \text { years }
$$

diesel oil:

$$
\mathrm{G}_{\text {gip }}=249.6 \cdot 10=2496 \mathrm{t} / \text { years }
$$

The price of liquefied natural gas is a moving value and depends on the place of purchase. For the calculation was adopted a price of $4.09 \$ / \mathrm{mmBTU}$ (1 million British Thermal Unit), where $1 \mathrm{mmBTU} \approx 27.096 \mathrm{~m}^{3}$. It follows that one cubic meter of liquefied natural gas costs $\$ 0.15$. As the cost of diesel oil was adopted as before 440 US dollars per ton.

$$
436117340 \cdot 0.15+2496 \cdot 440=66515841 \$
$$


Difficult to determine is the conversion price of the analyzed passenger/car ferry. Due to lack of access to engine prices, auxiliary equipment and shipbuilding costs themselves, the conversion cost, to be included, is strongly estimated.

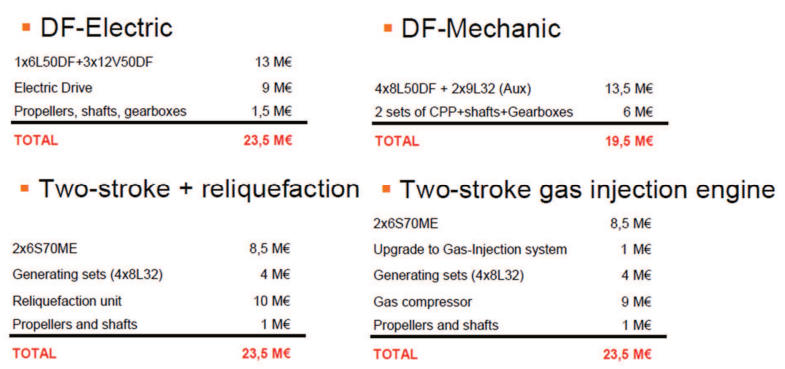

Fig. 6. Examples of engine prices [8]

As the cost of exchanging 4 main engines, 5 generating sets, LNG tanks and auxiliary equipment for the purpose of this article was accepted 20 million US dollars.

$$
66515841+20000000=86515841 \$
$$

The final cost estimates for 10 years of sailing MF Stena Spirit ferry was shown in the following Table 2.

Table 2. Compare the cost of individual solutions

\begin{tabular}{|c|c|}
\hline $\mathrm{SO}_{\mathrm{x}}$ emission reduction method & Estimated cost [MUSD] \\
\hline Use of low sulfur fuel & 140 \\
\hline Exhaust gas scrubbers + HFO & 99 \\
\hline Liquefied natural gas supply & 87 \\
\hline
\end{tabular}

All the above solutions have their advantages and disadvantages. Every shipowner should carefully analyze which solution is most beneficial in his case.

\section{Conlusions}

This article analyzes the available sulfur oxide emission reduction solutions on the example of a passenger-car ferry. Use of low sulfur fuel meeting emission standards, installation of exhaust gas scrubbers and modification unit for combustion of liquefied natural gas have been considered.

The main problem with the use of low sulfur fuels is its high price compared to heavy fuel oil (HFO), however, the lack of investment costs is an important issue for shipowners.

The use of exhaust gas scrubbers or unit conversion on LNG is a major investment and it is necessary to develop suitable space for the installation of new equipment and tanks. These solutions may be unprofitable on existing vessels whose planned life expectancy will be less than the time it takes to return the investment.

According to calculations in the article, in the case of the MF Stena Spirit ferry during the assumed operating period (10 years), the modification of the unit to liquefied natural gas and the investment in the exhaust gas scrubber will be returned. The use of low sulfur fuel during this time period would have been more expensive by 40 MUSD from the scrubber application and by 60 MUSD from the LNG supply. However, it should be borne in mind that fuel prices are not fixed and such assumptions can be variable.

Taking into account the large amount of time needed to return the investment and the complicated reconstruction of existing vessels, the option most likely to be chosen by the majority of shipowners is the use of low sulfur fuel. When building new units, the investment in exhaust gas scrubbers or LNG power is far more promising, and currently units are based on these technologies.

\section{Nomenclature}

DF dual fuel

DNV det norske veritas

ECA emission control area

HFO heavy fuel oil

IMO international maritime organization

LNG liquified natural gas

$\begin{array}{ll}\text { LSMGO } & \text { liquified natural gas } \\ \text { MGO } & \text { marine gas oil } \\ \text { PM } & \text { particulate matter } \\ \text { SCR } & \text { selective catalytic reduction } \\ \text { VOC } & \text { volatile organic compounds }\end{array}$

[6] Międzynarodowa Konwencja o Zapobieganiu Zanieczyszczaniu Morza Przez Statki 73/78, Tekst jednolity, 2015, 299-338.

[7] WOJTYTO, Z. Problemy eksploatacji dwusuwowych silników okrętowych na paliwach niskosiarkowych według doświadczeń firmy MAN Diesel. Silniki spalinowe. 2006, 45(3), 77-89.

[8] Wärtsila Dual Fuel LNGC, 2008.

[9] www.cleanmarine.no

[10] www.dupont.com

[11] www.shipandbunker.com

[12] www.shipspotting.com/gallery/photo.php?lid=1395782

[13] www.stenaline.pl 